\section{R Reyneke}

Senior Lecturer,

Department of Social

Work, University of the

Free State.

\section{DOl: https://dx.doi. org/10.18820/24150517/ JJS43.12.4}

ISSN 0258-252X (Print)

ISSN 2415-0517 (Online)

\section{Journal for Juridical}

\section{Science}

2018:43(2):79-108

\section{(C) Creative Commons} With Attribution (CC-BY)

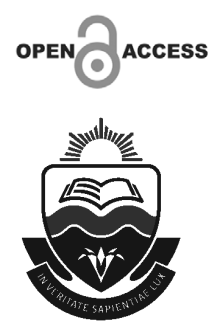

\section{The role of school social} workers in giving effect to children's right to education: A legal perspective

\begin{abstract}
Social workers are not commonly employed in South African schools. However, various role players, policy documents and court findings directly or indirectly refer to the need for social services for learners. Teachers cannot fully provide this service, since they are neither trained to do so, nor have the time to fully support the psychosocial development of learners - and this could be detrimental to the pursuit of quality education. This conceptual article argues that, although not many social workers are employed by the Department of Basic Education, social services as such should be a high priority in basic education. Policy frameworks, legislation and case law provide sufficient evidence that there is a need for more social workers in South African schools. These professionals are a necessity in order to ensure that learners' right to quality education is fully realised. The article also explains how school social workers could contribute to this quest for quality education, specifically, within the context of the $4 \mathrm{~A}$ framework. The article concludes with an outline of what could be expected from school social workers within the 4A framework.
\end{abstract}

\section{Introduction}

As a vulnerable group, children need special attention and protection. This protection is afforded by different legal enactments such as the Constitution of the Republic of South Africa (Constitution), ${ }^{1}$ the Children's Act, ${ }^{2}$ the Child Justice Act, ${ }^{3}$ and the South African Schools Act ${ }^{4}$ (Schools Act), as well as by national and

\footnotetext{
1 Constitution of the Republic of South Africa 1996.

2 Children's Act 38/2005.

3 Child Justice Act 75/2008.

4 South African Schools Act 84/1996.
} 
international policy documents endorsed by the South African government. ${ }^{5}$ The Children's Act ${ }^{6}$ states:

\begin{abstract}
All proceedings, actions or decisions in a matter concerning a child must - (a) respect, protect, promote and fulfil the child's rights set out in the Bill of Rights, the best interests of the child standard set out in section 7 and the rights and principles set out in this Act, subject to any lawful limitation.
\end{abstract}

In the process of protecting the best interests of children, ${ }^{7}$ their basic human rights have to be considered and protected, especially when making decisions regarding them. ${ }^{8}$ Furthermore, the best interests of the child standard provides for the physical and emotional security of children and their intellectual, emotional, social and cultural development. ${ }^{9}$ All these elements need to be considered holistically when working with, and planning for services aimed at children. This includes actions taken in the school environment. This article will focus on their right to education, ${ }^{10}$ and to social services. ${ }^{11}$ In what follows, the entwined nature of these two rights is explained and the fact that both these rights have to be secured in order to ensure not only education, but also quality education that will successfully prepare them for life after school. The important and unique contribution of the school social worker, who forms part of a multidisciplinary team in giving effect to these rights, will be the focus of this article.

Children are legally obliged to attend school until they have completed Grade 9 or reach the age of 15 years. ${ }^{12}$ During these years of compulsory education, educators have to ensure that they teach according to certain educational standards and that specified learning outcomes are reached. Various legal and developmental instruments such as the United Nations Convention on the Rights of the Child (UNCRC), ${ }^{13}$ the African Charter on the Rights and Welfare of the Child, ${ }^{14}$ and the National Development Plan $(\mathrm{NDP})^{15}$ recognise basic education as both a fundamental human right and a developmental priority. In this article, the international standard set by the Committee on Economic, Social and Cultural Rights (CESCR), as captured in General Comment 13 on the right to education, will be used as a conceptual framework. This framework, also known as the "four As

$5 \quad$ UNCRC 1989; Organisation of African Unity (African Charter on the Rights and Welfare of the Child) 1990; National Planning Commission 2012.

6 Children's Act 38/2005:sec. 6(2)(a).

7 Children's Act 38/2005:sec. 9.

8 Child Justice Act 75/2008:sec. 3(i); Children's Act 38/2005:sec. 8(2).

9 Children's Act 38/2005:sec. 7(1)(h).

10 Constitution of the Republic of South Africa 1996:sec 29; Committee on Economic, Social and Cultural Rights (CESCRGC 13), The right to education 1999:par. 6 (a-d).

11 Constitution of the Republic of South Africa Constitution 1996:sec. 28(1)(c).

12 Schools Act 84/1996:sec. 3(1).

13 UNCRC 1989:art. 29(1)(a).

14 Organisation of African Unity 1990.

15 National Planning Commission 2012. 
of education", provides an internationally accepted standard or indicator with regard to the realisation of the right to education. In this General Comment, the CESCR refers to the availability, accessibility, acceptability and adaptability (the "4 As") of education. ${ }^{16}$ It should be noted that the different dimensions of these standards do overlap and that the 4 As cannot be discussed in watertight compartments.

In addition, the aims of education also stipulate certain broad outcomes that have to be achieved in the education process. ${ }^{17}$ In this regard, art. 29(1) of the UNCRC ${ }^{18}$ provides as follows:

States parties agree that the education of the child shall be directed to:

a. The development of the child's personality, talents and mental and physical abilities to their fullest potential;

b. The development of respect for human rights and fundamental freedoms, and for the principles enshrined in the Charter of the United Nations;

c. The development of respect for the child's parents, his or her own cultural identity, language and values, for the national values of the country in which the child is living, the country from which he or she may originate, and for civilizations different from his or her own;

d. The preparation of the child for responsible life in a free society, in the spirit of understanding, peace, tolerance, equality of sexes, and friendship among all peoples, ethnic, national and religious groups and persons of indigenous origin;

e. The development of respect for the natural environment.

When analysing these aims, it becomes evident that two main aims are of relevance, namely the holistic development of the child's full potential (art. 29(1)(a)), and the preparation of the child to be a responsible citizen who will respect others' human rights (art. 29(1)(b)-(e)). ${ }^{19}$ In order to reach these educational outcomes, not only academic knowledge is important, but also the way in which children are perceived, treated and disciplined in the school context. To achieve this, learners will need a safe school environment that will contribute to their holistic development and that will play a part in developing their full potential.

Although school discipline is not a specific focus of this article, it plays a pertinent role when working with learners in schools. When trying to define 'discipline', it seems that educators have different opinions regarding the meaning of this concept. Some opine that it is about forming the moral character of the learner; others think of it as a process of exercising control over learners, using proactive and restorative measures; another group views it as a process to instil self-discipline, while some regard it

16 CESCRGC 13 1999:par. 6(a-d).

17 Reyneke 2013:287; UNCRC 1989:sec. 29(2); CESCR 1999:art. 13(1).

18 UNCRC 1989:art. 29(1)(a).

19 Reyneke 2013:287. 
very narrowly as punishment. ${ }^{20}$ The word 'discipline' is derived from the Latin word disciplina, meaning "instruction, tuition or teaching". ${ }^{21}$ It is thus clear that the original definition is very different from the opinions of some teachers on this topic. In this article, discipline will be referred to as:

\begin{abstract}
a teaching and learning process with two distinct aims: to create an orderly environment conducive to teaching and learning so as to enable the holistic development of every learner; and to teach learners to behave in a socially responsible manner and to develop self-discipline, which, ultimately, will result in respect for the rights and needs of others. ${ }^{22}$
\end{abstract}

As mentioned earlier, sec. 28(1)(c) of the Constitution stipulates that children have a right to social services, ${ }^{23}$ while sec. 8(5)(b) of the Schools Act $^{24}$ gives effect to this right by determining that school governing bodies (SGBs) have to ensure that support measures or structures for counselling are available for a learner involved in disciplinary proceedings. Jacobs v Chairman, Governing Body, Rhodes High School, and Others ${ }^{25}$ (Jacobs case) highlighted the need and obligation to provide social services and professional counselling for a troubled learner.

Professionals who are well equipped to provide such a counselling service are school social workers and psychologists. Regrettably, there are currently not nearly enough social workers employed by the Department of Basic Education (DBE) to ensure that the need for social services in schools is met. According to Kemp et al, ${ }^{26}$ approximately 148 social workers were employed by the DBE in 2015. Many of these social workers were employed at special schools and some in provincial offices. In 2016, there were 23719 schools in South Africa, ${ }^{27}$ which means that, even if these social workers were all part of district-based support teams, which they were not, each of them would be responsible for 160 schools. It is impossible for one person to provide psychosocial support and counselling services to as many schools as this. Fortunately, some SGBs have started to appoint school social workers, thereby increasing the number of these professionals. Although it is unclear how many social workers are employed by these SGBs, it is a step in the right direction in ensuring the availability of support and counselling services for learners with behavioural problems. At this point, it has to be emphasised that social workers are not simply responsible for managing disciplinary problems. They also have a role to play in the prevention of

20 Lessing \& De Witt 2010:24.

21 Lewis \& Short 1962:587.

22 Reyneke 2013:47.

23 Constitution of the Republic of South Africa 1996.

24 South African Schools Act 84/1996.

25 Jacobs v Chairman, Governing Body, Rhodes High School, and Others 2011 (1) SA 160 (WCC).

26 Kemp et al. 2015:28.

27 Colditz "Education problems: Are Afrikaans schools to blame?", https://www. news24.com/Columnists/GuestColumn/education-problems-are-afrikaansschools-to-blame-20180118 (accessed on 19 January 2018). 
disciplinary problems and in the provision of social services. Many children experience social hardship, but do not present with extreme behavioural problems because of their inner resilience. Since troubled and untroubled youths have a right to social services, the school social worker could directly or indirectly ensure that this right is realised by working towards decreasing risk factors present in the school and in the wider social environment of the learner. ${ }^{28}$

When analysing educational policies and annual reports, it becomes clear that the emphasis is on physical poverty, special needs, safety of school infrastructure, and quality of education, to name but a few. ${ }^{29}$ Unfortunately, it appears that the introduction of more social workers who can aid in the psychosocial support and development of children is not an explicit priority of the DBE. ${ }^{30}$ However, the Department is open for student social workers to do their practical work in schools. ${ }^{31}$ (National Planning Commission, 2012:303; South African Human Rights Commission, 2012) The NDP ${ }^{32}$ (National Planning Commission, 2012:367) refers to the need for the availability of services aimed at access to nutrition, health care, education, social care and safety. Furthermore, it declares that the state should provide more effective social welfare services for vulnerable groups such as children, and play a larger role than it currently does. This implies that the Departments of Basic Education (DBE) and Social Development (DSD) should work closely in ensuring psychosocial services for children. ${ }^{33}$ Yet, the abovementioned number of social workers in schools does not reflect this priority.

Although an application for the registration of school social work as a field of specialisation was submitted to the South African Council for Social Service Professions (SACSSP) in 2015, it is still not acknowledged as a specialised field in social work. ${ }^{34}$ As part of this quest for recognition, more research should be done in order to refine the contribution of social workers in schools.

The aim of this article is to indicate how school social workers could support schools to respect, protect, promote and fulfil the rights of children to education and to social services, and to show how they could contribute to providing quality education for learners. To achieve this, reference will be made to the internationally recognised educational standards of availability, accessibility, acceptability and adaptability (4 As) of education..$^{35}$ Attention will first be paid to what school social work entails. This will be followed by a discussion on the 4A framework. The role of the school social worker in this framework will continuously be highlighted.

28 Day \& Kearney 2016:991-992.

29 UNCRC 1989; Department of Basic Education 2016; Department of Education 2001; UNICEF South Africa 2006.

30 Department of Basic Education 2015; 2016; 2017.

31 Department of Basic Education 2017:189.

32 National Planning Commission 2012.

33 Department of Education 2001; Department of Social Development 2013.

34 Kemp et al. 2015.

35 CESCRGC 13 1999:par. 6(a-d). 


\title{
2. School social work
}

Social services are mainly provided by social workers working for the DSD, non-governmental organisations (NGOs), or community-based organisations. ${ }^{36}$ Social workers are tasked with improving the social functioning of people through the promotion of social change, problemsolving in respect of human relationships, and the empowerment and liberation of people to enhance their well-being. Social work further utilises theories of human behaviour; it intervenes at the point where people interact with their environment. ${ }^{37}$ This includes the school as an environment, as it is a place where children interact with others. Since the school environment plays such a considerable role in their current and future development, strengthening children's social functioning and creating a supportive environment are critical to ensuring children's wellbeing and to realising their right to education.

In order to conceptualise how social work can contribute to the $4 \mathrm{~A}$ framework of quality education, 'school social work' needs to be defined. According to Kemp et al.., ${ }^{38}$ school social work:

\begin{abstract}
... [addresses] social, emotional and behavioural barriers to learning experienced by learners at an educational institution from an ecological systems theory and strengths-based perspective. These services are aimed at supporting learners, parents, educators and the school as a community. One of the core functions of the School Social Worker is to ensure that learning and development take place through early identification of psychosocial barriers and appropriate intervention. Through preventative and developmental service delivery, care and support for teaching and learning (CSTL) are enhanced by providing all learners [with] the opportunity to access applicable resources to reach their full potential.
\end{abstract}

The authors argue that school social work not only contributes to the academic performance and overall well-being of learners in a healthy and safe school environment, but also helps enhance teachers' understanding of the social context of the child. ${ }^{39}$ Furthermore, it is also important to include the parents who experience social barriers when dealing with learners. ${ }^{40}$ It is, therefore, not only the learner with behavioural problems who needs the assistance of school social workers, but also the adults (parents and teachers) in the social environment of the learner.

36 Rautenbach \& Chiba 2010:29-34.

37 Department of Social Development 2006:51.

38 Kemp et al. 2015:9-10.

39 Kemp et al. 2015:10.

40 South African Counsel for Social Service Professions 2016:14. 


\title{
3. School social workers' contribution within the 4A framework
}

The 4A framework refers to the international requirement that education should be available, accessible, acceptable, and adaptable. ${ }^{41}$ This discussion will indicate that the psychosocial development of children as a developmental priority and a basic right is absent from this framework and that various policy documents, legislation and case law prescribe a stronger emphasis on the psychosocial development of children. The role of the school social worker in contributing to this framework will also be discussed. It will further be argued that school education is more than merely teaching academic content; it should also include the development of life skills and how to behave in a socially acceptable manner. Schools provide an ideal space where children who need social services can be identified and assisted. Without social workers in this space, the government loses out on an opportunity to ensure that it fulfils its constitutional obligation to respect, protect, promote and fulfil children's right to social services.

\subsection{Availability}

According to General Comment 13 of the CESCR on the right to education, 'availability' means that:42

\begin{abstract}
... functioning educational institutions and programmes have to be available in sufficient quantity within the jurisdiction of the State party. What they require to function depends upon numerous factors, including the developmental context within which they operate; for example, all institutions and programmes are likely to require buildings and other protection from elements, sanitation facilities for both sexes, safe drinking water, trained teachers receiving domestically competitive salaries, teaching materials, and so on; while some will also require facilities such as a library, computer facilities and information technology.
\end{abstract}

What stands out when analysing this comment is the concept of "functioning educational institutions and programmes". What does it mean for a school to have a well-functioning school and programme? The focus of the definition on what constitutes the availability of education is rather narrow. It refers mainly to the availability of infrastructure (classrooms, desks, chairs, and so on) and human resources (quality teaching staff) to ensure functioning educational institutions and programmes. But, on further scrutiny of the wider meaning of the availability of education to learners, it also includes much more, especially when considering the developmental context in which a school operates and the wider social environment. To guarantee the availability of a good educational programme, schools should ensure not only sufficient physical resources that will safeguard the physical health and safety of learners and teachers, but also the availability of psychosocial

41 South African Human Rights Commission 2012:12.

42 CESCRGC 13 1999:par. 6(a). 
support to provide an emotionally safe environment in which learners could thrive. Apart from the current measures available to schools, additional provisions should be made for the effective prevention and management of bullying, school violence, alcohol and drug abuse, and other social problems that learners may experience. ${ }^{43}$ Since these social problems may contribute to absenteeism, school dropout ${ }^{44}$ and uncontrollable behaviour, ${ }^{45}$ measures should be in place to support these learners emotionally. It will also contribute to the holistic development of learners when counselling and/or social services are available to them. ${ }^{46}$

Many learners come from social environments where they have experienced poverty and malnutrition, loss and trauma, as well as abuse and maltreatment, ${ }^{47}$ which impacts on the individual learner's ability to learn. Thus, the learners' ability to realise their right to education is compromised and unduly limited through their social environment. Some also experience psychological disorders, anxiety, high levels of stress, low emotional intelligence and a variety of other social problems. ${ }^{48}$

Apart from the impact of the social environment on the specific learner's education, these problems could also lead to behavioural problems in the classroom that may disrupt the educational process. This will make education unavailable to not only the affected learner, but also to the other learners. Since teachers are not fully equipped to deal with these problems, the need arises for the availability of social services and, specifically, school social workers who could provide this service. These professionals could also contribute to the holistic development of the learner, since they are skilled in "the development of the child's personality, talents, and mental and physical abilities". ${ }^{49}$

When acting out and socially unacceptable behaviour occur, disciplinary measures should not contribute to the problem, but ensure that the underlying problems are identified and resolved. It would thus be important to use disciplinary measures that are not physically and emotionally violent. Disciplinary measures should rather teach learners to take responsibility for their actions and to help them resolve the underlying reasons for the socially inappropriate behaviour. When learners and teachers are emotionally healthy, it contributes to an orderly environment that is conducive to teaching and learning. Although all the physical resources might be available, education can still be unavailable if the school or classroom environment is chaotic, due to the poor discipline of some learners.

43 Department of Basic Education 2008; 2014a.

44 Department of Basic Education 2011:3.

45 Barnes et al. 2012:71.

46 UNCRC 1989:art. 29(1)(a).

47 Department of Basic Education 2014b:4.

48 Castillo et al. 2013:883.

49 UNCRC 1989:art. 29(1)(a). 
A good example of how proper counselling and support services could have ensured a better learning environment is the well-known Jacobs case. ${ }^{50}$ In this case, a teacher was attacked with a hammer by a 13-yearold learner in the presence of other learners. During court proceedings, it was shown that, prior to the incident, the child had experienced psychosocial difficulties due to domestic and personal problems and that he had received limited counselling from the school counsellor, whose qualifications are unknown. When his behaviour had improved after five sessions, the counselling stopped without any follow-up interventions. ${ }^{51}$ The judge indicated that, had the child received sufficient counselling for his personal and family problems, the whole matter could have been avoided. ${ }^{52}$ Although there are no guarantees that psychosocial counselling and support to the family would have prevented this, had it been readily available and of a good standard, it could have protected the teacher, the innocent bystanders, and the child..$^{53}$ Although a teacher had identified that the child was experiencing social problems and had recognised the need for social services, nothing else had been done. Nobody from the school reached out to the DSD or any NGO to investigate, nor were any social services rendered to the child by the DBE. ${ }^{54}$ The judge found that the vice-principal had been negligent, since a reasonable person would have realised the need for more intensive intervention rather than mere counselling by a counsellor who focused only on the child's behaviour in class. ${ }^{55}$ The teacher who was attacked had also identified that the child was experiencing social problems, and, even though she cared, no professional help for the child had been secured. A discussion had taken place between the school and the mother and grandmother of the child. In addition, the few counselling sessions provided by the school counsellor had focused on the child's problems within the school, but not on his social and personal issues. ${ }^{56} \mathrm{~A}$ social worker, working holistically, would have contemplated the bigger picture and focused on improving the resilience of the child and thus his social functioning. ${ }^{57}$ The social worker would also have supported the teachers in dealing with the child. ${ }^{58}$ It also became clear during the proceedings that the counsellor was probably not professionally qualified, since she was of the opinion that the child had not been referred to her for his personal and social problems and that the vice-principal was dealing with these. ${ }^{59}$ As is evident from the registration documents of SAQA, it is highly unlikely that the vice-principal was

502011 (1) SA 160 (WCC).

51 Jacobs v Chairman, Governing Body, Rhodes High School, and Others:par. 39.

52 Jacobs v Chairman, Governing Body, Rhodes High School, and Others:par. 30.

53 Jacobs v Chairman, Governing Body, Rhodes High School, and Others:par. 49.

54 Jacobs v Chairman, Governing Body, Rhodes High School, and Others:par. 44.

55 Jacobs v Chairman, Governing Body, Rhodes High School, and Others:par. 44.

56 Jacobs v Chairman, Governing Body, Rhodes High School, and Others:paras. 9, 33, 38.

57 Kemp et al. 2015:24.

58 South African Counsel for Social Service Professions 2016.

59 Jacobs v Chairman, Governing Body, Rhodes High School, and Others:par. 37. 
adequately trained to deal with the personal and social problems of the child, since this type of acts does not form part of the training of teachers. ${ }^{60}$ It should also be noted that, in order to deal effectively with a child's social problems, statutory interventions are sometimes necessary. ${ }^{61}$ Educators do not have the right to perform statutory interventions, which include the removal of the child by means of a court order. Only some social workers can intervene through statutory measures. ${ }^{62}$ Another question could be raised as to the teacher's ability to successfully assess the child with regard to his psychosocial problems, since they are not trained to do this type of assessments. ${ }^{63}$ It is unfair and unethical to expect teachers to make such an assessment and provide counselling, as they are neither social workers nor psychologists.

Therefore, a well-functioning educational institution needs not only properly qualified teachers, but also school social workers, psychologists or access to adequate social services provided by the DBE, the DSD or NGOs.

If the DBE and SGBs thus want to improve the general functioning of educational programmes, social workers could provide psychosocial services for learners by attending to their social, emotional and behavioural needs - and this would be in line with the requirements of the Constitution, ${ }^{64}$ the Schools $A c t^{65}$ and international standards regarding the rights of children. ${ }^{66}$

Sec. $8(5)(B)$ of the Schools Act states that "the code of conduct must also provide for support measures or structures for counselling a learner involved in disciplinary proceedings"(RSA, 2011b). In Queens College Boys High School v Member of the Executive Council, Department of Education, Eastern Cape Government, Head of the Department of Education, Eastern Cape Province and Ten Others ${ }^{67}$ (Queens College case), learners were found guilty of the use of liquor and dagga on the school premises as well as insubordination towards the headmaster. They were subsequently expelled, but the DBE did not follow the SGB's recommendation for expulsion. The DBE claimed that the school had failed to provide proper support and counselling. ${ }^{68}$ The school applied to the court to have the decision of the DBE set aside. In the judgment, Judge Froneman referred to the need to provide rehabilitation services as part of disciplinary

60 South African Qualifications Authority 2018a; 2018b.

61 Children's Act 38/2005:secs. 150-152.

62 Children's Act 38/2005:sec. 105.

63 South African Qualifications Authority 2018a; 2018b.

64 The Constitution of the Republic of South Africa 1996:sec. 28(1)(c).

65 South African Schools Act 84/1996:sec. 8(5)(b).

66 UNCRC 1989:art. 29(1)(a).

67 Eastern Cape High Court case no. 454/08.

68 Queens College Boys High School v Member of the Executive Council, Dept of Education, Eastern Cape Government Head of the Dept of Education, Eastern Cape province and ten others 454/08:paras. 8, 28. 
procedures, in line with the provisions of sec. 8(5)(B) of the Schools Act. ${ }^{69}$ In this particular case, psychosocial counselling was required for the children with behavioural problems. It would, therefore, have been inappropriate for the DBE to expect teachers to deal with children with drug and alcohol problems/addictions, since they would at most be able to provide pastoral care to the learner. ${ }^{70}$ For them, to counsel learners would not be possible, since it does not fall within the guidelines of the training of educators and their norms and standards, and they would probably not have sufficient time available to do this. ${ }^{71}$

Sec. 10(4)(B)(ii) and (iii) of the Regulations of the Schools Act ${ }^{72}$ refers to a child attending counselling at district level and indicates that progress reports have to be submitted to the head of the department at provincial level when a child has been expelled. Unfortunately, this only refers to very serious misconduct(RSA, 2011a). Suspension and expulsion make education unavailable to affected learners. Therefore, preventative and early intervention social work services should be provided before serious misconduct has taken place.

It seems that, slowly but surely, the DBE is starting to understand the need for social services for children and that this could help make education available to learners. It has been reported that the DBE and different stakeholders are busy with a pilot project involving the testing of a referral system for psychosocial and health services and setting up a database of NGOs and other agencies that could provide these services. ${ }^{73}$ Furthermore, Goal 25 of the Educational Enrichment Programme (EEP) focuses on improved learner access to public services for, inter alia, psychosocial support. $^{74}$

The DBE and DSD are compelled to make provision for these services. In Centre for Child Law and Others v MEC for Education and Others, ${ }^{75}$ the then Department of Education failed to provide proper psychological support structures at a school of industry that focuses on children with behavioural problems. The Department claimed financial constraints as part of their defence. However, the judge referred to the fact that, when considering children's rights in comparison with other socio-economic rights,

[s]ection 28 of the Constitution contains no internal limitation subjecting them to the availability of resources and legislative measures for their progressive realisation. Like all rights, they remain subject to reasonable

69 Queens College Boys High School v Member of the Executive Council, Dept of Education, Eastern Cape Government Head of the Dept of Education, Eastern Cape province and ten others:par. 22.

70 Harley et al. 2000:292; Department of Education 2000; Schoeman 2015:121.

71 South African Qualifications Authority 2018a; 2018b; Department of Education 2000.

72 South African Schools Act 84/1996.

73 Department of Basic Education 2015:108.

74 Department of Basic Education 2015:117.

75 Centre for Child Law and Others v MEC for Education and Others 2008 (1) SA $223(\mathrm{~T}): 227$. 
and proportional limitation, but the absence of any internal limitation entrenches the rights as unqualified and immediate.

This sentiment of the court was confirmed by the Constitutional Court in Governing Body of Juma Musjid Primary School and Others v Essay NO and Others (Centre for Child Law and Another as Amici Curiae). ${ }^{76}$ Therefore, although budgetary constraints can be advanced as a reason for limiting psychosocial services, such limitation must be justifiable. Bearing the best interests of children in mind and the long-term consequences of the unavailability of the services concerned, the low priority assigned to these services in the allocation of resources gives rise to serious questions. ${ }^{77}$

In the Jacobs case, ${ }^{78}$ it was reported that the DBE was experiencing serious financial constraints and that it would have taken up to six months for it to provide psychosocial services for the child. ${ }^{79}$ It was further stated that, when DBE counsellors identified serious social problems, these would be referred to the DSD for intervention. The judgment indicates that it was, first and foremost, the school's duty to attend to the identified needs of the child and to inform the DSD that intervention was needed..$^{80}$ As argued earlier, financial constraints cannot provide unbridled justification for any failure to provide social services for children with serious behavioural problems. ${ }^{81}$ However, taking into consideration the financial constraints of the DBE and DSD, it is argued that prevention programmes should be in place to ensure that there are less children needing intensive psychosocial counselling. Social workers are skilled in providing training for teachers, learners, parents and other identified groups regarding social issues. ${ }^{82}$ Preventing social problems and addressing existing social problems could definitely help learners focus more on their academic work and thus make education more available.

Training teachers in the identification of social problems and in supporting learners through pastoral care ${ }^{83}$ could be helpful in managing learner problems and, thus, in improving the education environment. In the Jacobs case ${ }^{84}$ the judge indicated that it is the duty of educators to act when they become aware of social and other problems experienced by learners, since interventions could mitigate any possible harm to the child. A learner's aggressive and violent behaviour could traumatise

76 Governing Body of Juma Musjid Primary School and Others $v$ Essay NO and Others (Centre for Child Law and Another as Amici Curiae)2011 (8) BCLR 761 (CC).

77 Kemp et al. 2015:28.

78 Jacobs v Chairman, Governing Body, Rhodes High School, and Others.

79 Jacobs v Chairman, Governing Body, Rhodes High School, and Others:par. 40.

80 Jacobs v Chairman, Governing Body, Rhodes High School, and Others:paras. 40, 44.

81 See Centre for Child Law v MEC for Education:228.

82 Kemp et al. 2015; South African Council for Social Service Professions 2016:129.

83 Schoeman 2015.

84 Jacobs v Chairman, Governing Body, Rhodes High School, and Others:par. 44. 
innocent bystanders such as teachers and other learners. Through their interventions, social workers would be able to help prevent such problems by supporting teachers to identify the learners who are in need of counselling, and then provide the required help.

It cannot with certainty be said that the availability of psychosocial counselling services to the boy in the Jacobs case would have prevented the hammer attack and ensured the long-term availability of education for him. However, had it been available, it might have prevented the incident. Unfortunately, it happened, and this learner was eventually expelled and subjected to the South African criminal justice system. In addition, the teacher left the teaching profession, thus exacerbating the ever-increasing demand for qualified teachers. ${ }^{85}$ The unresolved trauma experienced by the witnesses to the event was in all likelihood immeasurable and might have influenced the academic performance of the witnesses or contributed to them dropping out of school. ${ }^{86}$

The addition of social workers to school staff could help manage the above-mentioned problems by means of explicit prevention programmes, support for Life Orientation teachers, and the prevention of disciplinary problems. Professional counselling services can address specific barriers to learning and the holistic development of the child.

\subsection{Accessibility}

Everyone should have access to educational institutions and programmes. ${ }^{87}$ In terms of General Comment 13 of the CESCR, access to schools consists of three overlapping dimensions, namely non-discrimination, physical accessibility, and economic accessibility. ${ }^{88}$ However, access to education entails more than physical access to a school or school grounds where discrimination or economic barriers are absent. Access to education can also be hampered, due to social and emotional barriers. Schools and the learning environment, in particular, should therefore also be socially and emotionally accessible. Reyneke ${ }^{89}$ adds another dimension, namely the responsibility to promote access to social services. All four dimensions can directly or indirectly influence the accessibility of schools.

School policies and practices that discriminate against learners could affect the accessibility of education for learners. Some children are more likely to be discriminated against than others, for example needy learners, children with behavioural problems, teenage mothers, and learners with

85 Hofmeyr \& Draper "Teachers in SA: Supply and demand - CDE", http://www. politicsweb.co.za/news-and-analysis/teachers-in-sa-supply-and-demand-cde (accessed on 26 April 2017).

86 Long 2015:9-14.

87 CESCRGC 13 1999:par. 6(b); Department of Education 2001; UNICEF South Africa 2007; Department of Social Development 2013.

88 CESCRGC 13 1999:par. 6(b).

89 Reyneke 2013:324. 
addiction problems. These learners, like any other learner, should be protected from any form of discrimination. ${ }^{90}$

Disciplinary measures used by schools can be discriminatory. Some examples of discrimination that have been exposed in schools are policies regarding hair styles ${ }^{91}$ and religious customs and beliefs. There is a good example of discrimination in the case of MEC for Education, KwaZulu-Natal, and Others $v$ Pillay (Pillay case)..$^{92}$ The respondent approached the SGB for exemption from the code of conduct so that she could wear a gold nose stud. This was in keeping with her family traditions and culture. The Constitutional Court ultimately found that there should have been dialogue in the school about the reasons why the learner wanted exemption from the code of conduct and that the request should not have been dismissed outright. The court held that the school should amend its code of conduct to make provision for exemption procedures, in order to accommodate religious and cultural practices. This, it stated, should take place after a process of proper consultation in terms of sec. 8 of the Schools Act. ${ }^{93}$

The court made it clear that, where there is a diverse learner body, provision should be made not to discriminate against minority groups. ${ }^{94}$

The vast majority of schools use a punitive system to deal with disciplinary problems..$^{95}$ In the process of disciplining, a learner's personal, family and social circumstances are not always considered prior to, and during these formal disciplinary procedures, with devastating consequences. ${ }^{96}$ In one particular instance, a boy from a poor socio-economic background stole school shoes, because the school would not allow him to wear sneakers to school. He was caught and eventually sentenced to imprisonment for theft. Poverty limited his access to school shoes and eventually to school and the furtherance of his education.(Jacobs v Chairman; Mercury Correspondent, 2012) When there is no money to buy school uniforms and provide food for lunch, children feel embarrassed and humiliated. This, in turn, could lead to disciplinary problems or to them not attending school at all, or even dropping out of school. ${ }^{97}$ This could also lead to other psychological consequences that warrant counselling and therapy. In many instances, the poverty experienced by children could be linked directly to absent parents,

90 Children's Act 38/2005:sec. 2(f).

91 Antonie v Governing Body, Settlers High School and Others 2002 (4) SA 738 (C); Henderson "Lesufi on hair protest: It was important that learners' views were heard", http://www.sowetanlive.co.za/news/2016/08/30/lesufi-on-hairprotest-it-was-important-that-learners-views-were-heard (accessed on 26 April 2017).

92 MEC for Education, KwaZulu-Natal, and Others v Pillay 2008 (1) SA 474 (CC).

93 South African Schools Act 84 of 1996.

94 MEC for Education, KwaZulu-Natal, and Others v Pillay 2008:paras. 68, 144, 166.

95 Jacobs v Chairman, Governing Body, Rhodes High School, and Others:par. 72.

96 Jacobs v Chairman, Governing Body, Rhodes High School, and Others:par. 57.

97 Masitsa 2006:166. 
divorce, alcoholism, unemployment, and other social evils to which these children are exposed. ${ }^{98}$

It is not disputed that schools need rules regarding school uniforms, since such rules do play a role in school discipline. ${ }^{99}$ What is problematic, however, is the situation where no support is provided for learners who cannot afford a proper school uniform. School social workers would be able to identify this type of problem and help the learner and his/her family solve it. Clothes banks and other community projects such as the establishment of community gardens could be introduced. Social workers are well equipped to initiate and manage such projects, freeing up teaching or preparation time for educators who are, in many instances, now burdened with these tasks.

When a learner is expelled because of behavioural problems, the DBE first has to approve this expulsion and find another school for the child. ${ }^{100}$ Many schools are understandably apprehensive to take these children because of their disciplinary history, making access to education for such children very difficult. If, however, psychosocial support and counselling were provided when the problem first arose, finding another school would, in many instances, not be necessary and the particular school would still be accessible to the learner.

Poverty is a huge problem in our communities and is relevant to the economic accessibility of education. Hungry children in schools have necessitated the introduction of a National School Nutrition Programme. In the 2014/2015 financial year, this programme provided nutritious meals for 19800 schools. ${ }^{101}$ It is to be expected that children who are hungry will experience difficulty in learning, thus making education inaccessible. ${ }^{102}$ Social workers, through community programmes, could help maintain these feeding schemes and so ensure that children in need are cared for. ${ }^{103}$

A final, but very common, example of disciplinary problems experienced in schools is the problem of children being late for school. Many of them have to travel long distances to school, ${ }^{104}$ and many have to walk to school or use buses and taxis. ${ }^{105}$ The cost of using public transport is high, adding to the economic hardships they experience. Bad weather could also make it difficult for these children to attend school, especially when their parents do not support their education. ${ }^{106}$ Punishing these learners without knowing and understanding their reasons could lead to aggressive behaviour and

98 Masitsa 2006:171; Mestry \& Khumalo 2012:107; Mgwangqa \& Lawrence 2008:23-24; Ward et al. 2015:70.

99 MEC for Education, KwaZulu-Natal, and Others v Pillay.

100 South African Schools Act 84/1996:sec. 9(5).

101 Department of Basic Education 2015.

102 Mgwangqa \& Lawrence 2008:23; Ward et al. 2015:69.

103 Mailhot 2015.

104 Mgwangqa \& Lawrence 2008:22.

105 Gustavsen 2010:23; Sampson \& Condy 2016:88.

106 Masitsa 2006:178. 
even dropout. This does not mean that all late-coming can be ascribed to social problems, but it has to be considered that there might be mitigating circumstances. Community and groupwork programmes that deal with the different elements of this issue could help prevent this problem.

Physical accessibility refers to the geographical reach of the school. Having a social worker on the staff would not necessarily make travelling safer. However, when learners experience trauma while travelling to and from school, psychosocial counselling could prevent potential behavioural problems as a result of the experience. The social worker could also contact the parents in order to determine safer travel options. Social workers could also use their community work skills to mobilise parents and other community members to ensure that learners stay safe. ${ }^{107}$ Child and youth care workers could also accompany children when travelling to and from school when they are available. These measures could make schools more accessible to learners.

Being physically and emotionally present at school may also be hampered by social factors within the school. It is a constitutional right of every learner to enjoy education in a peaceful and carefree environment. ${ }^{108}$ However, when learners experience violence in school, ${ }^{109}$ they do not enjoy such an environment, which leads to risk and lower levels of teaching and learning. ${ }^{110}$ Children bullying each other, and sometimes even their teachers, ${ }^{111}$ challenges teachers to provide quality education. Victims of bullying experience poor social and emotional well-being and are prone to poor academic performance. Moreover, being bullied may even have a negative impact on their success in later life. ${ }^{112}$ When learners are fearful of the school environment where they are the victims of violence, they cannot effectively deal with learning content, experience helplessness and rage, or totally collapse. ${ }^{113} \mathrm{~A}$ proper education is subsequently not available to them. Social workers can help deal with the bullies and address school climate issues through the use of the primary social work methods of community, group- and casework.

Social workers provide services to special schools where they support learners, as well as their parents and teachers. They also screen and assess new admissions and liaise with social workers and other professionals outside the school, making education accessible for children with special needs. ${ }^{114}$ Social workers employed in ordinary schools could also assess children with special needs and ensure that they are provided with special care, or refer them to special schools. They would also be able to develop programmes for children with special needs, for example

107 South African Council for Social Service Professions 2016:1-29.

108 Constitution of the Republic of South Africa 1996:secs. 12(c), 24(a), 28(1)(d).

109 Burton \& Leoschut 2013:129.

110 Barnes et al. 2012:69.

111 Mohlaloka et al. 2016:719.

112 Lomas et al. 2012:207.

113 Van der Kolk 2014.

114 Kemp et al. 2015:18. 
anti-bullying programmes, and programmes aimed at the prevention of teenage pregnancy and drug abuse. They could also ensure that children with attention deficit disorder (ADD)/attention deficit hyperactivity disorder (ADHD) receive the necessary medical interventions so that that they and the other children in the classroom can access the educational content.

This brings us to the last element of accessibility, namely the responsibility of the government to provide learners with access to social services. ${ }^{115}$ A good example of what can happen when a learner in need of social services is not provided with such a service is the Jacobs case ${ }^{116}$ discussed earlier.

Another example of the state being compelled to provide social services for learners is the case of the Centre for Child Law and Others $v$ Minister of Basic Education and Others. ${ }^{117}$ In this case, the Eastern Cape Department of Education refused to declare the posts of non-teaching staff for the 2013 book year. There was also a moratorium on the appointment of non-teaching staff, although this was budgeted for. Social workers and psychologists form part of this group of non-teaching staff. ${ }^{118}$ The court found that not providing for non-teaching staff was unlawful and also linked the work of non-teaching staff to the realisation of the right to basic education. ${ }^{119}$

Sec. $28(1)(c)$ of the Constitution ${ }^{120}$ provides for the right of children to social services. The problem is that there are not nearly enough employed professionals available to attend to the needs of these children. The NDP ${ }^{121}$ mentions the need for social workers, auxiliary social workers, community development workers, and child and youth care workers. It is estimated that South Africa requires roughly 55000 social service professionals to respond to the social welfare needs of the population. Currently, the number of registered professionals is uncertain, but, in 2012, there were approximately 15000 social service professionals registered with the South African Council for Social Service Professions. At present, there are social workers who are trained and able to provide these services, but they are not being employed by the government to render such services to learners. The reason for this might be financial constraints. ${ }^{122}$ There are thousands of learners in need of the care and support that only social

115 Reyneke 2013:324.

116 Jacobs v Chairman, Governing Body, Rhodes High School, and Others.

117 Centre for Child Law and Others v Minister of Basic Education and Others Case 1749/2012.

118 Department of Basic Education 2016:135.

119 Centre for Child Law and Others v Minister of Basic Education and Others:paras. 33, 34.

120 Constitution of the Republic of South Africa 1996.

121 National Planning Commission 2012:337.

122 Anon "More than 800 unemployed social workers must be accommodated", http://limpopoonline.co.za/?p=11956 (accessed on 8 June 2018); Magadla "Social work graduates battle to find work", http://www.dispatchlive.co.za/ news/2016/01/29/social-work-graduates-battle-to-find-work/ (accessed on 26 April 2017). 
service professionals can provide. If these learners do not receive these services, it could impact negatively on school discipline, leading to a school culture that is disruptive and eventually to good-quality education being made inaccessible to not only learners with social problems, but also to learners from well-functioning families.

\title{
3.3 Acceptability
}

General Comment $13^{123}$ of the CESCR provides that acceptability of education means the following:

\begin{abstract}
The form and substance of education, including curricula and teaching methods, have to be acceptable (e.g. relevant, culturally appropriate and of good quality) to students and, in appropriate cases, parents; this is subject to the educational objectives required by article 13(1) and such minimum educational standards as may be approved by the State.
\end{abstract}

Education for learners should thus be of a good quality and culturally appropriate. Even with the best-trained teachers and excellent educational content, education would not be of an acceptable standard if the environment in which it is provided is not of such a nature that it supports the quality of the content and teaching. The culture of the school thus comes into play. An appropriate school culture would contribute to making the environment a better place for teaching. In such an atmosphere, learners, teachers and other role players communicate with one another in a non-threatening manner; there is good discipline in the school; the general culture and climate are conducive to teaching and learning, and hardly any to no violence is experienced in the school. ${ }^{124}$ The social welfare of everyone is thus a priority; everyone's voice is duly considered; there are avenues to report unacceptable behaviour, and complaints are taken seriously and investigated properly. Furthermore, confidentiality is maintained and assistance is provided to everyone in need. All of these matters can be addressed by the school social worker.

Although art. 34 of the UNCRC ${ }^{125}$ provides that the child should be protected against sexual exploitation and sexual abuse, many learners still experience sexual violence, including sexual harassment, intimidation, and even rape. ${ }^{126}$ Male and female learners are also the victims of sexual abuse by teachers. ${ }^{127}$ These acts of violence in schools could be reduced by an improvement in the school culture and climate. ${ }^{128}$ Core dimensions of school life, including the safety of all concerned, teaching and learning, relationships, and the environment influence the climate of the school ${ }^{129}$

123 CESCRGC 13 1999:par. 6(c).

124 Barnes et al. 2012:72.

125 UNCRC 1989:art. 29(1)(a).

126 Netshitangani 2017:9169.

127 Netshitangani 2017:9169.

128 Barnes et al. 2012:69.

129 Barnes et al 2012:71; Cohen et al. 2009:180-181. 
As part of the school-based support team, social workers could facilitate a process of improving the culture of the school, since they are well trained in individual, group and community work. Interventions will include prevention programmes that focus on teaching empathy and improving interpersonal relationships, as well as supporting learners who have been the victims of abuse and violence, by providing counselling or referring them for further support. ${ }^{130}$ This could then assist in providing an environment that improves the general climate of the school, thereby ensuring that education is violence-free and thus acceptable to everyone concerned.

The aims of education must be considered in order to determine whether the standard of education is acceptable. Art. 29(a) of the UNCRC refers to the development of the child's personality, talents, as well as mental and physical abilities to his/her fullest potential. ${ }^{131}$ This shows that, in order for education to be of an acceptable standard, a holistic approach should be followed when working with children, in developing their personalities and in ensuring their mental well-being. Children who experience personal problems such as poverty, single-parent families, child abuse and neglect, discrimination and injustice are more likely to exhibit acting-out behaviours such as anger and aggression, vandalism, depression, and conflict with authority figures, and to experience low selfesteem. ${ }^{132}$ A holistic approach to developing the full potential of learners will thus include the teaching of academic content and life skills; cultural and sports activities, and the availability of psychosocial services that will help learners cope with what life throws at them. This is where the school's social worker can play a major role. The focus of the school as a whole should be on the development of the resilience of the learner. The Circle of Courage model that focuses on the development of belonging, mastery, independence and generosity could provide some guidance on how to improve the resilience of learners. ${ }^{133}$

Teachers sometimes have to supervise learners who are sent to detention after school hours because of poor behaviour or because they have not done their work. ${ }^{134}$ This could be more of a punishment for teachers than for learners and it is likely that the learners will not really learn something positive and educational from the experience. The effectiveness of this method in preventing further misconduct is also questionable. ${ }^{135}$ This has led to schools seeking alternative methods to discipline learners. Some of these measures include coaching teachers and learners; conflict resolution; reflection, and the restorative approach to school discipline. ${ }^{136}$ One of the aims of the restorative approach is to prevent misconduct and disciplinary

130 Department of Social Development 2013:37-39; Kemp et al 2015:24-25.

131 Willems 2010:937.

132 Brooks 2006:69; Geldenhuys \& Doubell 2011:324.

133 Van Bockern \& McDonald 2012:14-17.

134 Ashworth et al. 2008:22; Flannery et al. 2014:8.

135 Geldenhuys \& Doubell 2011:333.

136 Paterson, 2016; Thorsborne \& Blood 2013. 
action. ${ }^{137}$ This could be done by using techniques that ensure a connection between learners and their teachers and that develop the resilience of learners so that they can experience a sense of belonging, master their environment and have a say in what is happening to them. However, when misconduct occurs that negatively influences the quality of education, measures should be in place to deal effectively with the learners concerned. Social workers could use this 'detention time' to work with these learners in therapeutic and educational groups and address their underlying psychosocial needs, and, if necessary, provide further individual counselling. This will improve not only their academic achievements, but also their ability to function in a socially acceptable manner.

Another contribution of social workers could be to support and counsel teachers so that they can provide an acceptable standard of education. Although school social workers are not expected to counsel teachers, it is the ideal that they should. ${ }^{138}$ There is a great need to ensure the well-being of teachers, especially since it seems that the high degree of absenteeism among teachers is the result of burnout and other stress-related illnesses brought about by behavioural problems in the classroom. Teachers are also bullied by learners, which, in turn, contributes to burnout, deterioration of relationships with learners, and less motivated teachers. ${ }^{139}$ Other workrelated stressors such as the high marking/administrative workload; the lack of a learner ethic; poor learner attitudes; bureaucracy; struggling learners, and the impact of large classes on the well-being of teachers. Furthermore, personal stress is also experienced in the form of family issues, finances, health, and problems with time management. ${ }^{140}$ Teachers with poor psychosocial well-being will not be able to provide learners with an acceptable standard of education. Helping them will help the learners they have to teach. ${ }^{141}$ Social workers are suitably qualified to address these needs and stressors, since they are able to contribute to employee assistance programmes that could render services to unhappy educators who cannot optimally facilitate the development of the full potential of learners. ${ }^{142}$

\subsection{Adaptability}

According to General Comment 13, adaptability means that "education has to be flexible so that it can adapt to the needs of changing societies and communities and respond to the needs of students within their diverse social and cultural settings". ${ }^{143}$

137 Liebenberg et al. 2016:446.

138 Kemp et al. 2015.

139 Burton \& Leoschut 2013:24; De Wet 2012:239; Power 2017.

140 Govender "It's not kids bunking - it's teachers", https://mg.co.za/article/201606-02-its-not-kids-bunking-its-teachers (accessed on 22 August 2017); Johnson 2013:94.

141 Johnson 2013:30.

142 Mogorosi 2009:343-359.

143 CESCR 1999. 
In this description, two elements stand out. The first is that the school has to adapt to the needs of the society and the community in which it finds itself. According to the dictionary definition of 'adapt', it means to "change to fit a different situation". ${ }^{144}$ This then implies that, in order for schools to be adaptable, they should change in line with what happens in the broader society and the communities from which the learner comes, that is, they must adapt to the macro-level. An example of this could be the changes in the cultural composition of learners attending a school. If the school does not adapt to the needs of non-dominant cultural groups in a school, it can lead to conflict. ${ }^{145}$ The second element entails responding to the needs of learners, as they find themselves in a specific social and cultural setting, that is adapting to the meso-level. What this, therefore, means is that the school has to react to something that has happened - in this case, events in the social and cultural setting of the learner. ${ }^{146}$

In the first part of the description of 'adaptability', the CESCR ${ }^{147}$ refers to the environment outside the school, namely the community from which the learner comes. In doing so, it acknowledges that the learner must be seen and educated within a specific context, or, at least, the context from which the learner comes has to be considered when educating the learner. This is significant, because the school will then have to consider the social phenomena that are present in the community. The knowledge and skills of social workers would be valuable in this regard, since they are trained to do community analyses, interpret the results, and then develop programmes suitable for attending to the social problems experienced in the community. They would also be able to identify external resources that could help the school be more resilient and to attend to certain social problems. Disciplinary procedures, ${ }^{148}$ school uniform expectations, ${ }^{149}$ language policy, ${ }^{150}$ and the general culture of the school should thus be adaptable so as to ensure a caring and peaceful environment.

Social workers could contribute to the school environment becoming more adaptable to the needs of diverse learners, for example in a situation such as that in the Pillay case. ${ }^{151}$ Currently, social problems are widely experienced not only in our communities, but also in our schools. Many of these problems lead to high dropout rates, since learners do not have

144 Pharos dictionaries online "Adapt" https://www.pharosonline.co.za/search/any ?q=adapt\&titles=[10,1,30,230,52,200,240,51,260,170,180,250,67,150,55,58,190, $59,110,120,160,61,62,60,64,57,66,68,130,65,140] \& p=1$ (accessed on 16 January 2018).

145 Henderson 2016.

146 Merriam-Webster "Adaptability", https://www.merriam-webster.com/ dictionary/ (accessed on 29 January 2018).

147 CESCR 1999.

148 Jacobs v Chairman, Governing Body, Rhodes High School, and Others.

149 MEC for Education, KwaZulu-Natal, and Others v Pillay.

150 Head of Department, Mpumalanga Department of Education and Another v Hoërskool Ermelo and Another 2010 (2) SA 415 (CC).

151 MEC for Education, KwaZulu-Natal, and Others v Pillay. 
the psychological resilience to overcome daily obstacles. ${ }^{152}$ In general, children with behavioural and emotional problems are characterised by a difficult temperament, poor problem-solving skills, aggressive response choices, low levels of warmth and affection experienced at home, parents with a psychological pathology, especially depression, ineffective parenting, and socio-economic problems within the family. ${ }^{153}$ To ensure that physically and emotionally deprived children continue their schooling, they need a school environment that is adaptable and provides support and counselling for learners and, in some instances, their parents. ${ }^{154}$

It appears that ineffective parenting seems is an issue that contributes to behavioural problems on the part of learners. Social workers could develop and implement parenting programmes that would help parents be more effective in disciplining their children. In light of the ruling in YG $v$ the State and Others ${ }^{155}$ abolishing corporal punishment in the home, parents will have to be educated regarding appropriate, alternative disciplinary measures. School social workers would be in a position to provide this training or at least help with the creation of opportunities for other social workers to provide the training. Moreover, the creation of other social networks involving NGOs, church groups and sports clubs would assist in providing for the physical and emotional needs of learners and their parents. The school social worker could also provide support for teachers so that they are able to be more flexible concerning the needs of learners, by interpreting the influence of the wider community on learners and planning for their individual needs.

Upon reflection, it is clear that learners are faced with many social problems and that they have hardly any support in dealing with them. In order for education to be adaptable, schools should develop new strategies and policies to help learners cope with these problems and so ensure that they not only continue their education, but also have sufficient emotional energy to spend quality time on their academic work. Restorative disciplinary processes, psychosocial support and counselling services are thus needed. Since the DBE, DSD and most of the schools are currently not providing enough of these services, the system will have to start using more social service professionals to ensure urgent attention to the matter.

Specific services that will have to be attended to include protection in the form of promoting the well-being of learners, as well as services to families with a specific focus on life-skills programmes, parenting skills, and prevention services. ${ }^{156}$ In addition, services rendered to the youth should focus on prevention programmes that emphasise:

152 Mgwangqa \& Lawrence 2008:16-32.

153 Hemphill \& Littlefield 2006:330.

154 Mgwangqa \& Lawrence 2008:16-32.

155 A263/2016. Unreported case.

156 Department of Social Development 2006:21-23. 
- HIV/AIDS;

- Life orientation;

- Substance abuse;

- Life skills, especially soft skills;

- Mental health, and

- Addiction. ${ }^{157}$

These programmes will make schools more adaptable, since flexibility regarding the needs of learners is necessary to ensure education in a system that is currently struggling to provide quality education for all its children.

\section{Conclusion}

It is clear that, as a developmental priority, the psychosocial development of children in schools is mostly absent from the 4A framework and that various policy documents and case law prescribe a stronger emphasis on such development of learners. Various role players could contribute to the psychosocial development of learners. Sometimes, some of these roles and responsibilities of teachers, psychologists and social workers may overlap. In this article, the focus is on what the social worker could contribute. It does not dispute the fact that other professionals have a unique contribution to make, however, since school social work is still in its infancy; it provides some suggestions for what social workers can contribute.

Table 1 provides a summary of the contributions that school social workers can make at the different levels of the $4 \mathrm{~A}$ framework. 
Journal for Juridical Science (Special Issue) 2018:43(2)

Table 1: Responsibilities of the school social worker at the different levels of the 4A framework

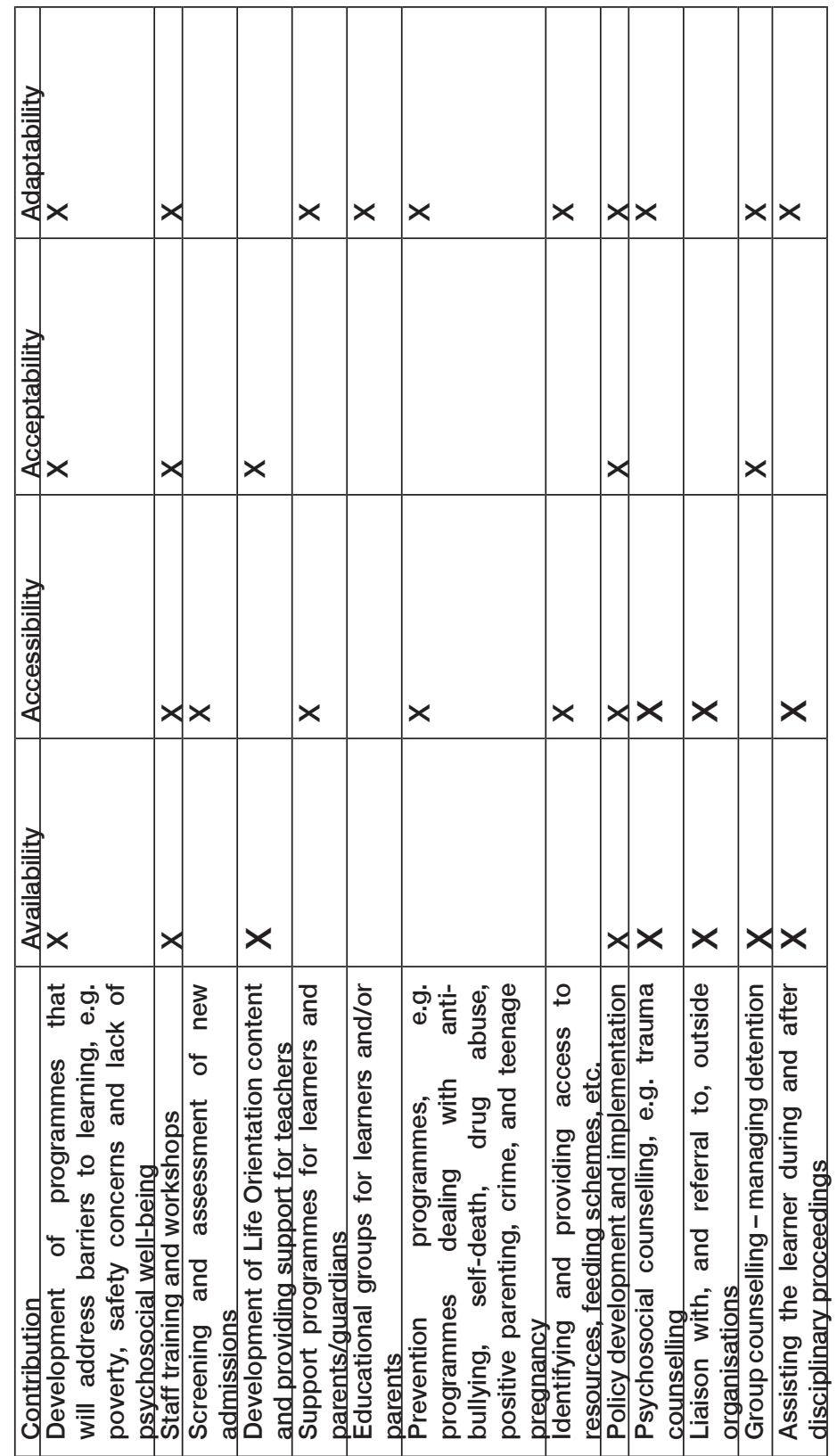


Social workers are not the silver bullet that will solve all the problems of schools and of the communities from which learners come. However, they do have skills and knowledge that teachers do not have, and their contribution in schools can help create a school environment that will fulfil children's right to basic education and to social services. It can thus be argued that the DBE should make it a developmental priority to create more posts for social workers in schools. SGBs could also consider obtaining these services, in order to ensure the emotional well-being of both learners and teachers. Further research on the contributions that school social workers, as part of a multidisciplinary team, could make in order to improve the psychosocial functioning of learners should also be investigated.

\section{Bibliography}

\section{ANON}

2017. More than 800 unemployed social workers must be accommodated. http://limpopoonline.co.za/?p=itzd11956 (accessed on 8 June 2017).

\section{ASHWORTH J, VAN BOCKERN S, AILTS J, DONNELLY J, ERICKSON K \& WOLTERMANN J}

2008. An alternative to school detention. Reclaiming Children and Youth 17(3):22-26.

\section{BARNES K, BRYNARD S \& DE WET C}

2012. The influence of school culture and school climate on violence in schools of the Eastern Cape Province. South African Journal of Education 32:69-82. https://doi.org/10.15700/saje.v32n1a495

\section{BROOKS JE}

2006. Strengthening resilience in children and youths: Maximizing opportunities through the schools. Child \& Schools 28(2):69-76. https://doi. org/10.1093/cs/28.2.69

\section{BURTON P \& LEOSCHUT L} 2013. School violence in South Africa. Results of the 2012 National School Violence Study. Cape Town: Centre for Justice and Crime Prevention.

CASTILLO R, SALGUERO JM, FERNÁNDEZ-BERROCAL P \& BALLUERKA N 2013. Effects of an emotional intelligence intervention on aggression and empathy among adolescents. Journal of Adolescence 36(5):883-892. https:// doi.org/10.1016/j.adolescence.2013.07.001

\section{COHEN J, MCCABE EM \& MICHELLI NM}

2009. School climate: Research, policy, practice, and teacher education. Teachers College Record 111(1):180-213.

\section{COLDITZ P}

2018. Education problems: Are Afrikaans schools to blame? https://www. news24.com/Columnists/GuestColumn/education-problems-are-afrikaansschools-to-blame-20180118 (accessed on 19 January 2018). 
COMMITTEE ON ECONOMIC, SOCIAL AND CULTURAL RIGHTS (CESCR) 1999. (CESCRGC 13) General Comment No. 13. The right to education (art. 13) E/C.12/1999/10. Geneva: Office of the United Nations High Commissioner for Human Rights.

\section{DAY T \& KEARNEY CA}

2016. Resilience variables and posttraumatic symptoms among maltreated youth. Journal of Aggression, Maltreatment \& Trauma 25(9):991-1005. https:// doi.org/10.1080/10926771.2016.1236358

\section{DE LANNOY A, LAKE SS AND SMITH C (EDS)}

2015. South African child gauge. University of Cape Town: Children's Institute.

\section{DEPARTMENT OF BASIC EDUCATION (DBE)}

2008. Care and support for teaching and learning (CTSL) programme. http:// www.education.gov.za/Programmes/HealthPromotion/CSTL.aspx (accessed on 27 July 2017).

2011. Report on dropout and learner retention strategy to Portfolio Committee on Education. (June):1-9.

2014a. Policy on screening, identification, assessment and support. Pretoria: Government Printer.

2014b. Discipline Summit. Discipline in schools revisited: Striking a balance between ethics and legislation. Boksburg.

2015. Annual report 2014/15. Pretoria: Government Printer.

2016. Annual report 2015/16. Pretoria: Government Printer.

2017. Annual report 2016/17. Pretoria: Government Printer.

\section{DEPARTMENT OF EDUCATION (DOE)}

2000. Norms and Standards for Educators. Government Gazette 20844 (volume 415) Pretoria: Government Printer.

2001. Education White Paper 6. Special needs education: Building an inclusive education and training system. Pretoria: Government Printer

\section{DEPARTMENT OF SOCIAL DEVELOPMENT (DSD)}

2006. Integrated service delivery model. Pretoria: Department of Social Development.

2013. Framework for social welfare services. Pretoria: Government Printer.

\section{DE WET C}

2012. Risk factors for educator-targeted bullying: A social-ecological perspective. Journal of Psychology in Africa 22(2):239-244. https://doi.org/10.1 080/14330237.2012.10820523

\section{FLANNERY KB, FENNING P, KATO MM AND MCINTOSH K}

2014. Effects of school-wide positive behavioral interventions and supports and fidelity of implementation on problem behavior in high schools. School Psychology Quarterly 29(2):1-14. 


\section{GELDENHUYS J AND DOUBELL H}

2011. South African children's voice on school discipline: A case study. International Journal of Children's Rights 19(2):321-337. https://doi. org/10.1163/157181811X547254

\section{GOVENDER P}

2016. It's not kids bunking - it's teachers. https://mg.co.za/article/2016-06-02its-not-kids-bunking-its-teachers (accessed on 22 August 2017).

\section{GUSTAVSEN B}

2010. Review of KJ Gergen. Relational being: Beyond self and community. International Journal of Action Research 150(2):226-230.

\section{HARLEY K, BARASA F, BERTRAM C, MATTSON E \& PILLAY S} 2000. "The real and the ideal": Teacher roles and competences in South African policy and practice. International Journal of Educational Development 20:287-304. https://doi.org/10.1016/S0738-0593(99)00079-6

\section{HEMPHILL SA \& LITTLEFIELD L}

2006. Child and family predictors of therapy outcome for children with behavioral and emotional problems. Child Psychiatry and Human Development 36(3):329-349. https://doi.org/10.1007/s10578-005-0006-1

\section{HENDERSON R}

2016. Lesufi on hair protest: It was important that learners' views were heard. http://www.sowetanlive.co.za/news/2016/08/30/lesufi-on-hair-protest-it-wasimportant-that-learners-views-were-heard (accessed on 26 April 2017).

\section{HOFMEYR J \& DRAPER K}

2015. Teachers in SA: Supply and demand - CDE. http://www.politicsweb. co.za/news-and-analysis/teachers-in-sa-supply-and-demand--cde (accessed on 26 April 2017).

\section{JOHNSON SM}

2013. Impact of stress and burnout interventions on educators in high-risk secondary schools. PhD thesis, Stellenbosch, Stellenbosch University.

\section{KEMP RJ, KEMP R, PRETORIUS E \& AVENANT J}

2015. Application for school social work as a specialisation area. A National Association of Social Workers SA submission to the South African Council for Social Service Professions. Edenvale: National Association of Social Workers SA.

\section{LESSING AC \& DE WITT MW}

2010. Karakterbou en Christelike waardes vir die bevordering van gedissiplineerde klaskamergedrag: 'n Kritiese beskouing. Tydskrif vir Christelike Wetenskap 46(1):21-37.

\section{LEWIS TL \& SHORT C}

1962. A Latin dictionary. Founded on Andrew's Edition of Freund's Latin dictionary. Revised, enlarged and in great part rewritten. Oxford: Clarendon Press. 


\section{LIEBENBERG E, HAY $J$ \& REYNEKE R}

2016. Die ontwikkeling van ' $n$ herstellende geregtigheidsprogram as vernuwende benadering tot die hantering van uitdagende leerdergedrag in Suid-Afrikaanse skole. LitNet Akademies 13(2):435-468.

\section{LOMAS J, STOUGH C, HANSEN K \& DOWNEY L}

2012. Brief report: Emotional intelligence, victimisation and bullying in adolescents. Journal of Adolescence 35(1):207-211. https://doi.org/10.1016/j. adolescence.2011.03.002

\section{LONG NJ}

2015. Perspectives on conflict in the classroom after fifty years. Reclaiming Children and Youth 24(1):9-14.

\section{MAGADLA Q}

2016. Social work graduates battle to find work. http://www.dispatchlive.co.za/ news/2016/01/29/social-work-graduates-battle-to-find-work/ (accessed on 26 April 2017).

\section{MAILHOT J}

2015. Green social work and community gardens: A case study of the North Central Community Gardens. University of Nordland.

\section{MASITSA G}

2006. Drop-out in township secondary schools: Educators' perspectives. Acta Academica 38(3):165-191.

\section{MERRIAM-WEBSTER}

2018. "Adaptability". https://www.merriam-webster.com/dictionary/ (accessed on 29 January 2018).

\section{MESTRY R \& KHUMALO J}

2012. Governing bodies and learner discipline: Managing rural schools in South Africa through a code of conduct. South African Journal of Education 32:97-110. https://doi.org/10.15700/saje.v32n1a402

\section{MGWANGQA V \& LAWRENCE L}

2008. Why do learners drop out of school? Learner perceptions in the Fort Beaufort District, Eastern Cape, South Africa. Commonwealth Youth Development 6(2):16-32.

\section{MOGOROSI L}

2009. Employee assistance programmes: Their rationale, basic principles and essential elements. Social Work/Maatskaplike Werk 45(4):343-359.

MOHLALOKA SMB, JACOBS L \& DE WET C

2016. The influence of traditional male initiation (lebollo) on school discipline: Educators' perspectives. Deviant Behaviour 37(6):709-721. https://doi.org/10.1 080/01639625.2015.1071132

\section{NATIONAL PLANNING COMMISSION (NPC)} 2012. National Development Plan 2030. Our future - make it work. Pretoria: Government Printer. 


\section{NETSHITANGANI T}

2017. School management teams' perspective of the gendered nature of school violence in South African public schools. Gender \& Behaviour 91699177.

NICHOLAS L, RAUTENBACH J \& MAISTRY M (EDS)

2010. Introduction to social work. Claremont: Juta.

\section{ORGANISATION OF AFRICAN UNITY (OAU)}

1990. African Charter on the Rights and Welfare of the Child. OAU doc. CAB/ LEG/24.9/49 (1990). http://www1.umn.edu/humanrts/africa/afchild.htm (accessed on 23 March 2015).

\section{PATERSON J}

2016. New direction for school detention. https://www.districtadministration. com/article/new-direction-school-detention (accessed on 19 May 2017).

\section{PHAROS DICTIONARIES ONLINE}

2018. "Adapt". https://www.pharosonline.co.za/search/any?q=adapt\&titles=[10 ,1,30,230,52,200,240,51,260,170,180,250,67,150,55,58,190,59,110,120,160,61,6 $2,60,64,57,66,68,130,65,140] \& p=1$ (accessed on 16 January 2018).

\section{POWER T}

2017. School violence. In F Veriava et al. (eds) 2017:293-309.

\section{RAUTENBACH $\mathrm{J} \&$ CHIBA $J$}

2010. Introduction. In L Nicholas et al. (eds) 2010:3-38.

\section{REYNEKE JM}

2013. The best interests of the child in school discipline in South Africa. Tilburg University.

\section{SAMPSON C \& CONDY J}

2016. One teacher's experiences of teaching reading in an urban multi-grade foundation phase class. Perspectives in Education 34(2):81-96. https://doi. org/10.18820/2519593X/pie.v34i2.7

\section{SCHOEMAN S}

2015. Towards a whole-school approach to the pastoral care module in a postgraduate certificate of education programme: A South African experience. European Journal of Teacher Education 38(1):119-134. https://doi.org/10.1080/ 02619768.2014.892576

\section{SOUTH AFRICAN COUNCIL FOR SOCIAL SERVICE PROFESSIONS (SACSSP)}

2016. Scope of practice: Social work final draft. Pretoria: South African Council for Social Service Professions.

\section{SOUTH AFRICAN HUMAN RIGHTS COMMISSION (SAHRC)}

2012. SAHRC Charter of Children's Basic Educational Rights. South African Human Rights Commission. http://www.sahrc.org.za (accessed on 11 March 2018).

\section{SOUTH AFRICAN QUALIFICATIONS AUTHORITY (SAQA)}

2018a. Registered qualification: Bachelor of Education. http://allqs.saqa.org. za/showQualification.php?id=20161 (accessed on 17 October 2018). 
2018b. Registered qualification: Master of Education: Teaching. http://allqs. saqa.org.za/showQualification.php?id=21474 (accessed on 17 October 2018).

\section{THORSBORNE M \& BLOOD P}

2013. Implementing restorative practices in schools. A practical guide to transforming school communities. Kindle edition. London: Jessica Kingsley Publishers.

\section{UNICEF SOUTH AFRICA}

2006. The child friendly school manual. Pretoria: UNICEF.

2007. A human rights-based approach to education for all. Pretoria: UNICEF.

\section{UNITED NATIONS COMMITTEE ON THE RIGHTS OF THE CHILD \\ (UNCRC) \\ 1989. The Convention on the Rights of the Child. Resolution: UN doc. A/44/49. http://www2.ohchr.org/english/law/crc.htm (accessed on 7 June 2017).}

\section{VAN BOCKERN S \& MCDONALD T}

2012. Creating Circle of Courage schools. Reclaiming Children and Youth 20(4):14-17.

\section{VAN DER KOLK B}

2014. The body keeps the score. Mind, brain and body in the transformation of trauma. Kindle edition. New York: Viking.

\section{VERIAVA F, THOM A \& HODGSON TF (EDS)}

2017. Basic education rights book. Johannesburg: Section27.

\section{WARD C, MAKUSHA T \& BRAY R}

2015. Parenting, poverty and young people in South-Africa: What are the connections? In A De Lannoy et al. (eds) 2015:69-74.

\section{WILLEMS J}

2010. Children's rights and human development. A multidisciplinary reader. Antwerp: Intersentia. 